\title{
Horner syndrome as a manifestation of thyroid carcinoma: a rare association
}

\author{
Síndrome de Horner como manifestação clínica de \\ carcinoma da tireoide: uma associação rara
}

Bernardo Pereira', Tiago Silva', Henrique Luiz', Isabel Manita', Luísa Raimundo', Jorge Portugal'

\section{SUMMARY}

An 82-year-old patient presented a progressively growing hard thyroid nodule, and left ptosis. Additionally, ophthalmologic evaluation revealed ipsilateral miosis, diagnostic findings of Horner syndrome. Computerized tomography revealed a $7.5-\mathrm{cm}$ thyroid mass infiltrating the main neck vessels. Although clinical and imaging data were suggestive of poorly differentiated thyroid carcinoma, fine-needle aspiration led to the diagnosis of papillary carcinoma. Paliative care was proposed to the patient due to the advanced stage of the neoplasm and to significant comorbidities. Horner syndrome is an infrequent manifestation of thyroid disorders and benign etiologies are more often implied. Malignant thyroid neoplasms represent a rare cause of Horner syndrome. However, an appropriate and prompt diagnosis is paramount for timely treatment of rare thyroid malignancies. Arq Bras Endocrinol Metab. 2013;57(6):483-5

\section{SUMÁRIO}

Paciente de 82 anos apresentando-se com nódulo tireoidiano de crescimento progressivo e ptose palpebral esquerda. 0 exame oftalmológico revelou ainda miose ipsilateral e achados diagnósticos de síndrome de Horner. A tomografia computadorizada mostrou massa tireoidiana de $7,5 \mathrm{~cm}$ infiltrando os grandes vasos do pescoço. Apesar dos dados clínicos e imagiológicos sugestivos de um carcinoma pouco diferenciado da tireoide, a citologia aspirativa foi diagnóstica de carcinoma papilar. Em função do estádio avançado da neoplasia e das comorbilidades significativas, foi proposta para terapêutica paliativa. A síndrome de Horner é uma manifestação clínica infrequente em tumores tireoidianos, estando as condições benignas maioritariamente implicadas. As neoplasias malignas da tireoide representam uma causa rara de síndrome de Horner. Contudo, um diagnóstico adequado e expedito é fundamental para o tratamento atempado nos raros casos de malignidade da tireoide. Arq Bras Endocrinol Metab. 2013;57(6):483-5

Correspondence to: Bernardo Pereira Serviço de Endocrinologia, $8^{\circ}$ piso Hospital Garcia de Orta, E. P. E. Av. Torrado da Silva 2801-951 - Almada, Portugal bern1981@gmail.com

Received on Feb/14/2013 Accepted on Mar/5/2013

\section{INTRODUCTION}

$\mathrm{H}$ orner syndrome (HS) is a clinical entity classically characterized by ipsilateral ptosis, miosis, and anhydrosis, being induced by lesions in the oculosympathetic tract. Although several etiologies may cause HS, neoplasms are most commonly implicated. In rare circumstances, thyroid disorders may be associated with HS, and benign diseases predominate (1).

We report here a case of HS as the presenting symptom of a locally advanced thyroid carcinoma.

\section{CLINICAL CASE}

An 82-year-old female was referred to our department with a 9-month history of a progressively growing thyroid nodule. The patient refused any initial investigation to her primary care physician. She mainly complaint of left eyelid dropping in the previous 6 months. Past medical history was relevant for colon adenocarcinoma 12 years before, and uncontrolled hypertension. There was no previous history of head and neck irradiation, nor family history of thyroid carcinoma. 
At physical examination, a hard left cervical nodule fixed to deep structures was noted close to the thoracic inlet. Ophthalmologic evaluation revealed $3.11-\mathrm{mm}$ left ptosis (Figure 1), and right and left pupillary diameters measuring 4.9 and $7 \mathrm{~mm}$, respectively, diagnostic findings of HS.

Analytic surveys revealed normocytic normochromic anemia (10.8 g/dL, reference: 11.5-18), elevated serum creatinin $(2.7 \mathrm{mg} / \mathrm{dL}$, reference: $0.7-1.2)$ and erythrocyte sedimentation rate $(61 \mathrm{~mm} / \mathrm{s}$, reference: $<30)$. She had low free T4 $(0.74 \mathrm{ng} / \mathrm{dL}$; reference: $0.93-1.7)$ but normal free $\mathrm{T} 3(3.38 \mathrm{pg} / \mathrm{mL}$; reference: 2.57-4.43) and TSH (0.2 mUI/L; reference: 0,1-4), as well as other pituitary hormones, cortisol and IGF-1 (data not shown). Cervical ultrasonography (US) revealed a hypoecoic mass in the left thyroid lobe with central vascularization and margins indistinct from posterior structures. US-guided fine needle aspiration (FNA) showed hypercellularity with nuclear overlapping, intranuclear inclusions and grooves, diagnostic features of papillary thyroid carcinoma. Cervical computed tomography $(\mathrm{CT})$ revealed a $7.5-\mathrm{cm}$ heterogeneous left thyroid mass with focal necrosis and macrocalcifications, laterally displacing the trachea (Figure 2 ), and compressing main neck vessels posteriorly, with margins indistinct from these structures (Figure 3). Left cervical (segments III and IV) and inferior paratracheal adenopathies were also noted, with no other potential metastasis in thoracic and abdominal regions. Brain magnetic resonance showed recent and past vascular ischemic lesions in the frontal cortex that were otherwise unremarkable.

A multidisciplinary team discussion concluded that, due to the locally advanced agressive thyroid carcinoma and the overall clinical context (advanced age, stage 4 chronic renal disease - MDRD formula - and cerebrovascular disease), the patient was not fit for any surgical or medical curative approach, and supportive care was proposed.

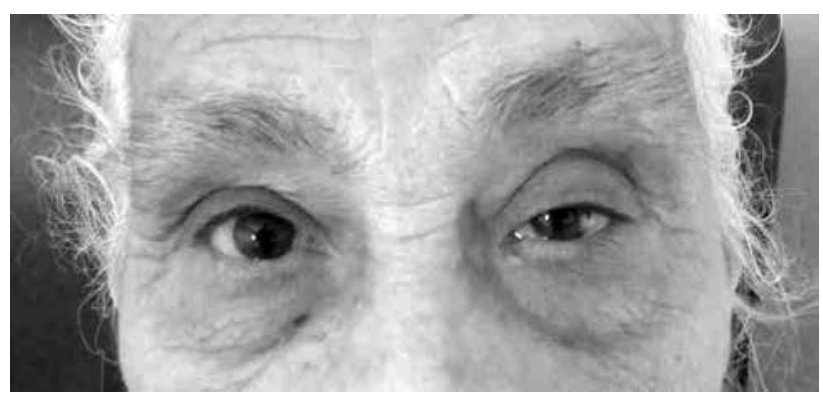

Figure 1. Left ptosis in Horner syndrome associated with thyroid carcinoma.

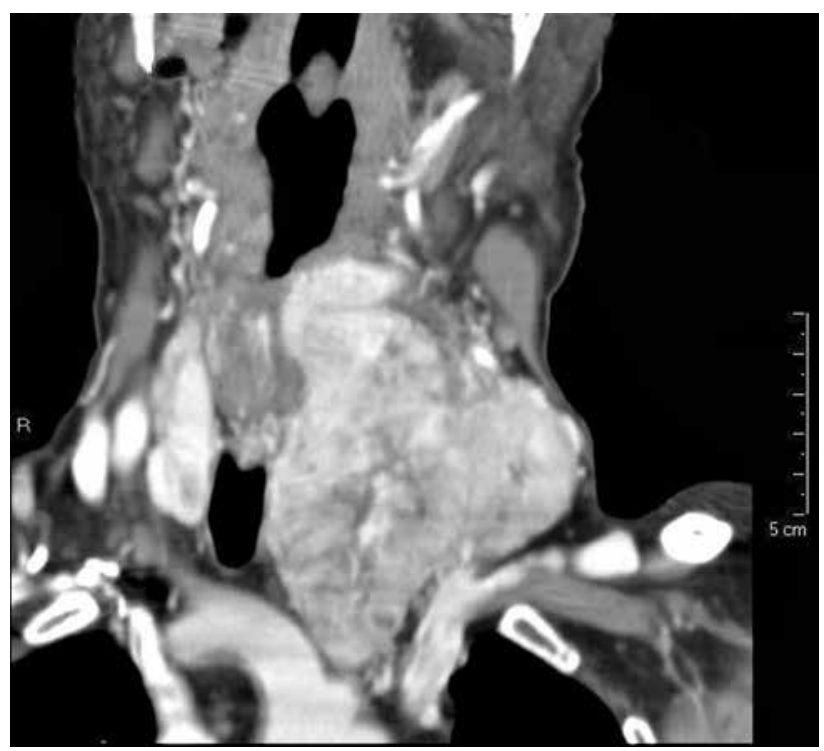

Figure 2. CT coronal section: cervical mass with lateral displacement of the trachea and extension to mediastinum.

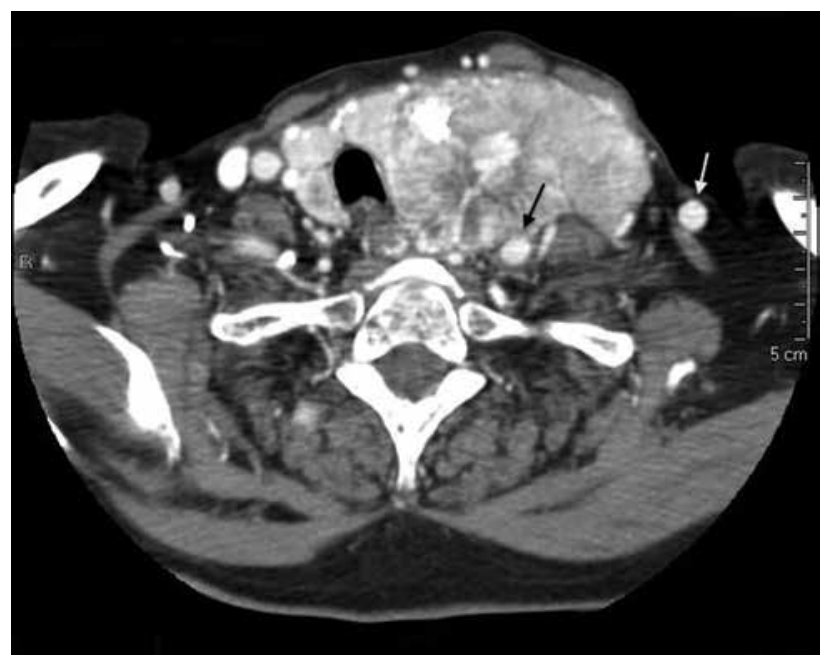

Figure 3. CT axial section: cervical mass displacing laterally the internal jugular vein (white arrow), without distinct margins (focal invasion) from common carotid artery (black arrow).

\section{DISCUSSION}

HS was first described by Johann Horner in 1869 as a consequence of lesions anywhere along the oculosympathetic trunk $(2,3)$. This pathway can be viewed as a three-neuron chain of hypothalamic origin. The first neuron descends through the brainstem to the spinal cord, where it synapses in the inferior cervical and superior thoracic segments (C8-T2). Then, the preganglionic segment (second neuron) emerges to incorporate to the sympathetic trunk, which crosses the brachial plexus over the apex of the lung and ascends to synapse 
in superior cervical ganglion, close to the carotid bifurcation. The third neuron enters the skull in association with the internal carotid artery, passes through the cavernous sinus to the orbit and the eye, where it enervates the dilator muscle of the pupil, Mueller's muscle of eyelids and the lacrimal sac (4).

As in the case of our patient, oculosympathetic tract injuries most often occur in the pregaglionic region (21-67\%), with neoplastic disruption being the most common etiology (1). Infrequently, thyroid disorders can induce HS $(3,5)$. Benign etiologies are most commonly implicated (83\%), with multinodular goiter being the most frequent reported lesion (1). Thyroid malignancy is a rare cause of HS, with a frequency of $0.4-0.9 \%$ in the two largest reviews of its etiology $(3,5)$. Although the type of thyroid malignancy is often unreported in HS $(1,3,5)$, anaplastic carcinoma has the potential to be more commonly involved due to its local aggressiveness $(2,6)$. In our patient, given the clinical and imagiologic data suggestive of an aggressive behavior, poorly differentiated thyroid carcinoma was at least likely the cause of neurological damage. Failure to diagnose it by US-FNA could be related to aspiration in well-differentiated neoplastic areas.

Physical examination is essential for the diagnosis of HS and pharmacological tests can be performed to confirm (cocaine and apraclonidine) (7) and localize (hidroxianphetamine) (3) the lesion. This initial approach identify the level of the lesion in $60-62 \%$ of cases $(3,8)$. Cervical CT is a recommended imaging method when investigating HS, and except when obvious causes are suspected (e.g. trauma, surgery), it should always be performed, given the possibility of life-threatening conditions, such as occult thyroid carcinoma (9).

Preoperatively, FNA is essential not only for diagnostic purposes but also for therapeutic decisions. As an example, cytological diagnosis of thyroid lymphoma as the cause of HS should lead to chemotherapy and radiotherapy as first line approaches (10).

The recognition of thyroid disorders in association with HS should lead to short-term surgical intervention, not only to increase the likelihood of neurologic recovery $(2,6,11)$, but also to improve survival, as it is the case of anaplastic thyroid carcinoma (12).

In conclusion, we present a rare case of HS in association with a thyroid carcinoma of aggressive behavior.
Although the cause of HS in thyroid disease is fairly often benign, appropriate investigations and timely treatment approach are paramount due to the possibility of a rare life-threatening thyroid malignancy.

Acknowledgements: Valeriano Horta Leite, MD, PhD (Departamento de Medicina, Serviço de Endocrinologia, Instituto Português de Oncologia de Lisboa, Francisco Gentil, E. P. E.) and Jorge Rosa Santos, MD (Departamento de Cirurgia, Serviço de Cirurgia de Cabeça e Pescoço, Instituto Português de Oncologia de Lisboa, Francisco Gentil, E. P. E.) for providing their extensive clinical experience in Thyroid Oncology. António Alves de Matos, MD (Serviço de Radiologia, Hospital Garcia de Orta, E. P. E.) and Carlos David Santos, MD (Serviço de Anatomia Patológica, Hospital das Clínicas da Universidade Federal do Triângulo Mineiro, Uberaba, MG) for their valuable contribution.

Disclosure: no potential conflict of interest relevant to this article was reported.

\section{REFERENCES}

1. Leuchter I, Becker M, Mickel R, Dulguerov P. Horner's syndrome and thyroid neoplasms. ORL. 2002;64(1):49-52.

2. Harding J, Sywak M, Sidhu S, Delbridge L. Horner's syndrome in association with thyroid and parathyroid disease. ANZ J Surg. 2004;74(6):442-5.

3. Maloney W, Younge B, Moyer N. Evaluation of the causes and accuracy of pharmacologic localisation in Horner's syndrome. Am J Ophthalmol. 1980;90(3):394-402.

4. Kardon R. Anatomy and physiology of the autonomic nervous system. In: Miller NR, Newman NJ, Biousse V, Kerrison JB, editors. Walsh and Hoyt Clinical Neuro-ophthalmology. 6th ed. Baltimore: Williams \&Wilkins; 2005. p. 674-6.

5. Giles C, Henderson J. Horner's syndrome: an analysis of 216 cases. Am J Ophthalmol. 1958;46(3 part 1):289-96.

6. Yip D, Drachtman R, Amorosa L, Trooskin S. Papillary thyroid cancer presenting as horner syndrome. Pediatr Blood Cancer. 2010;55(4):739-41.

7. Kedar $S$, Biousse $V$, Newman N. Horner's syndrome. In: UpToDate, Brazis $P(E d)$, UpToDate, Waltham, MA, 2012. Available from: http:// www.uptodate.com/contents/horners-syndrome?source=search_res ult\&searc=horner\&selectedTitle=1\%7E99. Accessed on: Oct 15, 2012.

8. Almog $Y$, Gepstein R, Kesler A. Diagnostic value of imaging in Horner syndrome in adults. J Neuro-Ophthalmol. 2010;30(1):7-11.

9. Lee J, Lee H, Lee D, Choi C, Kim S, Suh D. Neuroimaging strategies for three types of Horner syndrome with emphasis on anatomic location. Am J Roentgenol [serial on the internet] 2007Jan [cited 2012 Dec 29]; 188 (1):w74-w81. Available from: http://www. ajronline.org/content/188/1/W74.long. Accessed on: Nov 7, 2012.

10. Billie J, Wetzel W, Suen J. Thyroid lymphoma with adjacent nerve paralysis. Arch Otolaryngol. 1982;108(8):517-9.

11. Broome J, Gauger P, Miller B, Doherty G. Anaplastic thyroid cancer manifesting has new-onset Horner's syndrome. Endocr Pract. 2009;15(6):563-6.

12. Lowry S, Shinton R, Jamieson G, Manche A. Benign multinodular goitre and reversible Horner's syndrome. BMJ Clin Res Ed. 1988;296(6621):529-30. 